\title{
UNHCR in Turkey
}

\author{
Elif OzMEnEK
}

\section{Abstract}

This paper uses an in-depth case study of Turkey to examine the complex and contemporary challenges facing the UNHCR. The work of the UNHCR Turkey Program presents a unique example of the problematic relationship between a nation-state and an international refugee regime. The Turkish government ratified the 1951 Convention relating to the Status of Refugees in March 1962, but maintains the geographical limitation restricting its asylum commitment to applicants from European countries. Turkey, one of only two countries among the signatories of the Convention that keeps the geographical limitation, relies mostly on the UNHCR's eligibility assessment of non-European asylumseekers. Although the focus of the paper is a country-specific example, its goal is to establish a model that can be used in evaluating any UNHCR regional or country program.

\section{Résumé}

Cet article tente d'examiner les défis complexes contemporains confrontant le HCR par le biais d'une étude en profondeur de la Turquie. Le programme du HCR pour la Turquie est un exemple unique de la relation problématique pouvant exister entre un état-nation et un régime international sur le droit d'asile. Le gouvernement de la Turquie a ratifié en mars 1962 la Convention des Nations Unies de 1951 relative au statut des réfugiés, mais continue à maintenir les restrictions géographiques, limitant ses engagements envers seulement les demandeurs provenant de pays européens. La Turquie est l'un des deux seuls pays parmi les signataires de la convention à maintenir une restriction géographique. Pour ce faire, il s'appuie principalement sur la notion de test d'admissibilité de demandeurs d'asile noneuropéens. Quoique que l'article porte sur l'exemple d'un pays spécifique, son but ultime est d'établir un modèle pouvant servir à l'évaluation de n'importe quel programme du HCR dévoué à une région ou à un pays.

\section{Introduction}

7 he establishment of the United Nations High Commissioner for Refugees (UNHCR) in 1951 created a new stage for a more institutionalized and international refugee regime. Until that time, it was presumed that individuals must belong to a state to ensure their protection and give that state responsibility for (or control over) them. Refugees, on the other hand, were stateless people, so they were a predicament, for they denied and challenged the protection and accountability of their own countries. ${ }^{1}$

With the 1951 Convention and the 1967 Protocol, the UNHCR created an international norm and law establishing the right for an accepted "refugee" to have international protection. As the main international institution dealing with refugees, the UNHCR began to implement several solutions: voluntary repatriation, integration into the country of first asylum, and the resettlement into a third country of asylum to ease the refugee burden. However, within a complex system for dealing with refugee plight, where refugees are outcomes of a political decision taken by a nation-state, but solutions to their well-being expand beyond that nation-state, the UNHCR continues to face new challenges and complications.

In the last two decades of the twentieth century, the globalization of capitalist economy has deepened the economic gap between the wealthy North and the poor South. The rapid increase in the number of the states with diverse regimes and global communication and transportation systems, ongoing ethnic wars, the dissolution of the Soviet Union, and the institutional growth of the European Union further complicated the refugee issue. "Overforeignerization" ${ }^{2}$ of Europe has created greater discrimination, racism, xenophobia, and the resurgence of culturalspecificity claims and restrictive cultural identities. The growth of Islam as a European religion and the increased migration of foreigners disturb many Europeans who see 
their own culture threatened. Today Europe maintains more rigid limitations along its borders. As a result, 80 per cent of the world's refugees flee one poor country for another.

As former un High Commissioner Sadako Ogata observes, " $[\mathrm{I}] \mathrm{t}$ was in Europe that institution of refugee protection was born, it is in Europe today the adequacy of the system is being tested." ${ }^{3}$ Within such an era the UNHCR Turkey branch presents a unique example of the contemporary problematic relationship between a nation-state and an international refugee regime.

This paper evaluates the work of the UNHCR through the country-specific example of Turkey. The Turkish government ratified the 1951 Convention relating to the Status of Refugees in March 1962, but maintains the geographical limitation restricting its asylum commitment to applicants from European countries. Turkey, one of only two countries among the signatories of the Convention that keeps the geographical limitation, relies mostly on the UNHCR's eligibility assessment of non-European asylum-seekers. Non-European refugees are granted temporary asylum in Turkey following a status-determination procedure in which the UNHCR Branch Office-opened in Ankara in 1960 - plays a key role. Nearly all these refugees need to be resettled through the UNHCR.

This paper, however, uses a country-specific example to examine the complex and contemporary challenges facing the UNHCR today, and performs a three-level analysis that can form the basis for an evaluation model for any regional/ country program. This analytical approach categorizes the challenges of the UNHCR in three broad areas: external, internal, and collaborative challenges.

\section{UNHCR and Its Contemporary Challenges in a Country Program}

Since this paper concerns itself with a country-specific examination of the organization, the focus will be on these challenges through the lens of the Turkey Country Program. As a consequence of Turkey's application for geographical limitation, the UNHCR's biggest responsibility in Turkey is the assessment of eligibility of non-European asylum-seekers. This responsibility comes with other considerations, including protection of non-European refugees and asylum-seekers by ensuring access to fair and efficient refugee-status determination procedures, and by providing assistance pending resettlement or lasting solutions. However, the main challenges should be evaluated within a broader perspective. To analytically examine these challenges, the study is categorized into external, internal, and collaborative challenges.

\section{External Challenges}

In the un system, which is founded in the idea of nationstates, the concept of refugee is still closely tied to the understanding of state sovereignty, national security, and membership, making the topic of refugees complex. As Arthur Helton argues, the contemporary refugee dilemma is, as the UN or regional organizations extend treaty protection and strengthen enforcement mechanisms, that governments can still reduce the protection. ${ }^{4}$ The impact of donor politics on UNHCR practices, the political and economical importance of the country within the un system, and the human rights record of the country in which the UNHCR operates, create a real challenge.

In international relations literature there are four broad areas that affect a country's refugee policies: bureaucratic choices, international affairs, the national security considerations of the host country, and the absorption capacity of the local host community. In this study, these areas are accepted as external challenges to the UNHCR's activities.

The nation-state uses its own authority in deciding which bureaucratic mechanism to use when dealing with refugee issues. In cases where states allocate responsibility to a civilian state agency, such as the Ministry of the Interior or a social welfare agency, it is usually an indication that refugee policies are determined by the high politics of the country. ${ }^{6}$ Most of the time, in states that handle refugee issues as a part of their high politics, the military becomes involved in decision making. Military involvement in refugee issues demonstrates clear concern for national security, in which case the national authorities see the refugee cause as an extra burden and are reluctant to consider the welfare of refugees. However, if a refugee agency is in charge of refugee issues, as is the case in most Western countries, then refugee policies are a part of low politics of the country. In this case, the refugee policies of states tend to be more liberal and open.

The international affairs of the country are crucial to the determination of its bureaucratic choices. International assistance, a negative international reputation, and publicity may influence a state's bureaucratic choice on refugee policies. However, a host community's perceptions of international organizations can also play an important part in decision making. The level of politics at which refugee issues are decided may affect local attitudes towards international assistance and cooperation. Nation-states are very sensitive to issues directly related to their national sovereignty. As Jacobsen observes, "[by] demonstrating that borders cannot be controlled, a mass influx challenges and undermines the government's sovereign right to determine 
who enters its territory." 7 Government dependency on international assistance during a mass influx may lead to the idea that with this assistance other entities may find a right to intervene in the state's domestic affairs and that idea may cause resentment toward the international community.

Local absorption capacity relies primarily on economic self-sufficiency and social receptivity. Social receptivity is largely determined by the cultural meaning of refugees, which is influenced by cultural, historical, and religious factors. ${ }^{8}$ When refugees are thought to cause social problems, public sympathy dies.

Threat to security is another external challenge. The conventional understanding of national security is based on the concept of external or internal military threat. The revisionist view departs from the militaristic conception of its inclusion in wide-ranging issues like the environment and economic factors. The third conception of security is a combination of these two: it perceives security as an external problem of wide scope as well as internal threats to its unity and integration. Refugees threaten all three dimensions of security. ${ }^{9}$

Within this perspective this paper tries to understand how Turkey's multiple roles challenge UNHCR's activities.

\section{Turkey as a Country Producing Refugees and Internally Displaced People}

Turkey has been one of the most common countries of origin among asylum seekers in Europe, especially since the 1980s. The first wave of Turkish asylum seekers to Europe came immediately after the military coup in 1980 and was followed by the escalating Turkish-Kurdish conflict in 1984. The numbers of asylum applications reached approximately 264,000 Turkish nationals, mostly of Kurdish origin, between 1990 and $1996 .{ }^{10}$ By some accounts, today Turkey has the second-largest population of internally displaced persons in the world. Since fighting between Kurdish PKK and the Turkish army began in 1984, an estimated 30,00o lives have been lost, and forcible evacuations led to the destruction of nearly 3,00o Kurdish villages. ${ }^{11}$ During most of the 1980 and 1990s, the government imposed a state of emergency on eleven provinces in the southeast. Conflict and fear created a larger migration. In July 1997, Turkey's deputy prime minister announced that 370,000 people had been forced to migrate during thirteen years of conflict. In 1994, Turkey's Minister of Human Rights said that 2 million people were without houses or a place to call home. The U.S. Department of State's 1997 Human Rights Report cited an estimated 560,000 people as internally dis- placed. ${ }^{12}$ The scope of action of security forces in southeast Turkey has included armed forays into Iraqi territory, which has negatively affected the living conditions of Iraqi Kurds.

\section{Turkey as a Transit Country}

The open-border policy within the European Union (EU) increased the importance of border-control policies for the peripheral states. On several occasions, Turkish authorities expressed their irritation at becoming a transit country as well as being a buffer zone between the East and the West. In many cases, Turkish authorities harshly criticized the Western countries for taking the most qualified or desirable refugees and leaving the rest to find their own way. The eu countries, on the other hand, criticized Turkey for not protecting its borders strictly enough against the trafficking of people. When over 1,200 persons arrived on the southeastern coast of Italy in 1998, Turkey as a transit country became an issue again. The majority of people arriving in Italy consisted of ethnic Kurds from Turkey and Iraq, as well as Egyptians, Bangladeshis, Sri Lankans, and Algerians.

While Turkish authorities announced that they would not be surprised by Ркк involvement in trafficking, a state secretary in the German Interior Ministry, Eduard Linter, stated that there was suspicion that Turkey was not doing as much as it could to stop the Kurds leaving the country, probably because of the dispute between Ankara and the Eu over Turkey's application for membership in the EU. He added, "It is hard to imagine Turkish security forces would not have noticed ships of this size."

In February 2000, 900 people of Kurdish descent were left on the shores of France. According to a New York Times report, the trafficking involved some Turkish nationals. This last development once more indicated the critical position of Turkey as a transit country.

\section{Turkey as a Country of Asylum}

In the past eleven years, there have been several large-scale influxes of refugees and persons in refugee-like situations: Iranians in the early 1980 s after the Islamic Revolution, Afghans in 1982, Iraqi Kurds in 1988 and 1991, Bulgarian Turks in 1989, Bosnians in 1992, and Kosovars in 1999. The estimated numbers of refugees are high: Nearly 1 million Iranians, about 60,00o Iraqi Kurds in 1988 and half a million in 1991, almost 300,000 Bulgarian Turks, 20,000 Bosnians, and 18,00o Kosovars found asylum in Turkey in little more than a decade. ${ }^{13}$ 


\section{Why Are Turkey's Multiple Roles Crucial to UNHCR Activities?}

Turkey's multiple roles in the refugee issue affect its refugee policies dramatically. In the last two decades, the emergence of Kurdish nationalism and the rise of Islam challenged the cultural homogeneity of Turkish society. On that account, national security became an internal and external problem for the state. Any refugee coming from Iran, Iraq, or Syria approached Turkey with skepticism. Influenced by their ethnic and religious background and by terrorism in the region, Turks saw Middle Eastern refugees as a security threat to Turkey's unity. Since the UNHCR was in charge of refugees from these countries, UNHCR and Turkish officials clashed over this issue. In the last decade, Turkish refugee policies focused increasingly upon security as a result of high involvement by the Ministry of the Interior and the Defence Ministry in refugee issues. During the fourteen years of conflict with the PKK, Turkish authorities promoted the slogan "Love or Leave Turkey" to contend with rebellious Kurds, and public sympathy for the Kurdish cause diminished. In the international arena, Turkey denied that internally displaced people were a problem, and the Turkish public as well as authorities began to denounce as betrayers any refugees who wished to resettle in another country. UNHCR's assistance to Iraqi Kurds was not well appreciated by Turkish society. Furthermore, high inflation and economic instability wore down the Turkish people, and the public came to believe that Turkey had insufficient resources to deal with refugees.

In its international relations Turkey always followed the "be the Western ally" model, its active involvement in NATO and the un a direct outcome of this foreign policy. However, the Eu's constant rejection of Turkey disillusioned the Turkish public. In the last ten years Turkey became a nearpariah state, because it was more concerned about its national security, more sensitive about intervention in its national sovereignty, and more skeptical about international humanitarian and human rights organizations. The more the West criticized Turkey's low profile on human rights, the more Turkey became negative about the NGOs and international organizations and started to perceive their assistance as an international intervention in its national sovereignty.

Within such a climate, the UNHCR's role was extremely sensitive, and Turkey's bureaucratic choices and international affairs, as well as the absorption capacity of the local community, created a direct challenge to the UNHCR.

\section{Internal Challenges}

Financial and human capital management are two important internal challenges that affect the UNHCR's activities and efficacy. In the Turkey Country Program, most refugees and many asylum-seekers rely on UNHCR's limited resources for material support, which takes the form of a monthly stipend, food, shelter, basic health care, and schooling, as well as legal and social counselling. Travel costs are also paid for refugees invited to Ankara for refugee-status determination and resettlement interviews.

In the UNHCR 2001 Global Appeal, the UNHCR Turkey Office listed the number of non-European refugees and asylum seekers of concern as 7,000. In addition, 670 Bosnian and Kosovar refugees and 2,550 Turkish returnees were provided with UNHCR assistance. The total financial cost is announced as US\$5.7 million dollars. In 1999, the UNHCR Global Report working budget for the UNHCR Turkey Office was Us $\$ 252,907$, and income from contributions was Us $\$ 1$ million. Given the number of refugees and the financial constraints of the UN system, monetary issues became a challenge for the UNHCR. While continuing to provide assistance, UNHCR had to become involved in a constant search for funding.

Human capital management is a challenge in itself. UNHCR's expanding program to train government decisionmakers and maintain public awareness requires an internal training program. Advocacy groups have raised several concerns about UNHCR's procedures and staff in Turkey. One of the biggest criticisms facing the UNHCR Ankara Office is the lack of standardized selection criteria for the eligibility interview. Although this would appear to be largely an institutional problem, it is actually a matter of internal staff training. The Ankara Office has also been criticized for the interpreters it used during the interviews. As a result, during the past three years, UNHCR Ankara moved away from the ad hoc use of interpreters and started employing full-time, trained interpreters. The absence of consistent gender-sensitive standards was identified as one major gap in the asylum system throughout the region. Subregional workshops on raising gender awareness started to be organized. Training of the national staff on cultural sensitivity and the need to leave personal beliefs and understandings outside the interview room, however, still remain challenges for the UNHCR.

A very substantial increase in asylum applications in the last decade has led to a backlog in applications. The result is that asylum seekers and UNHCR staff have become frustrated and/or overworked. The 1994 regulation identified the Ministry of the Interior (in collaboration with the UNHCR) 
as the final decision-making body for status determination, and therefore required that the national staff be in constant communication with the Turkish authorities. High stress and frustration reduced staff empathy for asylumseekers and refugees, or caused it to vanish entirely. The UNHCR Ankara Office is, however, very open to changes and learns a lot from different experiences, which is the biggest strength of the country program.

\section{Field Study Notes $^{14}$}

The basement of the UnHCR Ankara Office, where the asylum seekers are interviewed, is cold, dark, and depressing. Children whose parents are going through the process are hungry, crying, and bored. The frustration of mothers is reflected on the kids. No one really talks in the room, but there is an incredible noise in the air. On the fourth floor of the same building, the national staff of the UNHCR are wrestling with difficulties that the Turkish authorities give to the asylum seekers in the satellite cities and at the borders. On the third floor, the staff are worn out about the resettlement processes that last for years ... On the street across from the UNHCR building, children, women, and men are sitting in the dirt for days waiting for their claim to be heard.

A Canadian woman of Iranian descent who was also an asylum seeker ten years ago arrived as an intern to the UNHCR Ankara Office, to the place where she was granted refugee status. She was a Ph.D. student in Canada, working on game therapy for children. After her first week in the Office, she suggested she establish a playground in the basement for children. After her third week, she exhibited the pictures that children drew while they were waiting for their parents, on the third floor. She gave the children a "word" and wanted them to draw a picture of that word. The answers with crayons were very impressive. Happiness was black because the children did not know what it was, fear was the picture of the father, and sadness was a friend who was left back at home... That was the first time I felt that an actual bond was built between all the floors of the UNHCR Ankara Office.

\section{Collaborative Challenges}

In order to discover durable solutions, a variety of intermediary operating organizations, governments and the UNHCR must cooperate. This challenge has become more complicated since disseminating information about refugees, advising decision-making authorities, and taking a part in the determination of refugee status became a part of the UNHCR's responsibility. Support for the UNHCR's mandate from the political leadership, the higher levels of administration, and influential NGOS, as well as the public at large, is crucial for the adoption of policies and the success of its programs.
This paper distinguishes two different collaborative challenges that are crucial to the Turkey Country Program: collaboration with the resettlement countries, and collaboration with the national NGOS and implementing partners.

Since all non-European refugees must be resettled in a third country, collaboration with the resettlement countries is critical. The resettlement process take from six months to two years. This not only increases the financial strain on the country program but also creates psychological frustration for refugees. Once refugees are granted status, they must reside in the satellite cities determined by the Turkish government, where they are obliged to have signature duty. ${ }^{15}$ Children are not allowed to attend Turkish schools during this period. Any kind of schooling is not permitted in the satellite cities.

A shortened waiting period is the ideal solution for the UNHCR's problem. However, some resettling countries have a longer screening period for refugees from the Middle East. Resettlement countries might look at four criteria when determining acceptance of a refugee: whether the refugee's educational and professional background will make integration into the society possible, whether health is good or poor, whether the refugee's security screening is clear, and whether the refugee has a military background. However, besides being questionable on humanitarian grounds, these criteria can make the whole process longer than expected. By keeping foreign embassies in Ankara updated about the conditions of refugees in Turkey, the Office tries to establish more collaborative relationships with the resettlement countries.

Cooperation with implementing partners in Turkey is also critical to the success of the UNHCR. The UNHCR works with seven implementing partners: Anatolian Development Foundation, Argen Company, Association for Solidarity with Asylum-seekers and Migrants, Human Resource Development Foundation, International Catholic Migration Commission, and Turkish Red Crescent Society. To help serve non-European refugees, new partnerships were forged with NGOs. With the collaboration of its partners, UNHCR conducted research on the problems of refugees in Turkey, and led public information campaigns on community services. One great strength of the UNHCR Turkey Program is its collaborative relationship with its implementing partners.

\section{UNHCR in Turkey}

Turkey experienced the first mass influx of non-conventional refugees in 1988, when the Iraqi Kurds were attacked by the Iraqi government with chemical weapons. Thousands of civilian Kurds poured into Turkey in a matter of days. The Turkish government was initially against the idea of granting 
asylum to the Kurdish refugees. Many Turkish parliamentarians stated that it was ironic to accept thousands of Kurdish refugees while a conflict was going on with Kurdish guerrillas in southeastern Turkey. However, the next day the Turkish prime minister announced that the humanitarian dimension of the problem necessitated opening the borders. ${ }^{16}$ Because it was the first of its kind, this mass influx was full of ambiguities for the Turkish government. Some officials believed that under international law Turkey had no obligations to these refugees, while others were hesitant to employ the term refugee for this group of people. It was decided to call these people "temporary guests" or "Pershmergas" (members of an Iraqi Kurdish sect). For the UNHCR Ankara Office, an influx of this scale was also new. Turkish authorities feared that the intervention of the UNHCR might prevent voluntary repatriation or cause new waves of migration, so they refused to allow the UNHCR to extend its assistance and protection.

From 1988 to 1991, Europe was reluctant to accept Kurdish refugees from the camps on the Turkish border with Iraq, yet at the same time criticized Turkish officials for not providing adequate assistance. This tension led to a tug of war between the Turkish government and the West. Turkish officials refused to accept us $\$ 14$ million for providing better shelter and health conditions for the refugees, arguing that the aid was an attempt by Western officials to keep refugees in Turkey rather than repatriate them. ${ }^{17}$ Friction only increased while the situation remained unsolved. Meanwhile, Turkey faced another influx of 58,144 refugees after Iraq's invasion of Kuwait. Then in 1992, hundreds of Bosnians sought asylum in Turkey. Turkish officials requested that the UNHCR assist Bosnians who had sought temporary haven in Turkey. A camp was established near Kirklareli, and the UNHCR provided housing units and cash for other essential supplies and infrastructure. Today the UNHCR still continues to address the needs of the Bosnian population in Kirklareli and has started new projects to assist vulnerable Bosnian families_including households headed by women - children, and the elderly living outside the camp, mainly in Istanbul.

After the Gulf crisis (1990-1), there were new developments in Turkish governmental practice towards "nonConvention" refugees. With the establishment of a safe zone in northern Iraq, Turkey became more reluctant to accept asylum seekers. The result was even more friction between Turkey and the UNHCR, especially over asylum seekers who had been recognized as bona fide refugees as a result of human rights violations in Turkey itself. For example, when thousands of Turkish Kurds-mostly from Sirnak-fled Turkey in April 1994 as fighting erupted between Turkish forces and the PKк in southeast Turkey, the UNHCR assisted 8 ,ooo persons in towns and villages along the Iraqi side of the border. In July and August 1994, a second flow of refugees from villages in Hakkari arrived in northern Iraq. By the end of August, more than 10,000 people had settled across the border. However, the continuing conflict at the border put refugees at risk, and Turkish authorities denied permission for some NGOs to operate in the area. The UNHCR transferred 8,600 people to two sites in Atroush and established a sub-office in Dohuk to co-ordinate assistance in Atroush. While armed conflicts between the KDP (Kurdistan Democratic Party) and the PUK (Patriotic Union of Kurdistan) intensified, between March and May 1995 Turkish military operations scattered PKK elements throughout the Dohuk governorates. Turkish authorities insisted that a quick solution must be found for the Atroush camp, because they were convinced that the camp was a base for PKK terrorists. Ignoring Turkey's accusations, the UNHCR increased its presence in the area, although monitoring during the evenings became impossible for security reasons.

In October 1995, representatives of the KDP, PUK, Turkoman Front, Turkey, U.K., and the U.S. met in Ankara to discuss settlement of the conflict in northern Iraq. Article 22 of the final statement of the meeting stated that the participants agreed to work with and support the UNHCR for the immediate voluntary repatriation of Turkish citizens in the Atroush camp. On December 21, 1996, the UNHCR turned the camp over to the local authorities. ${ }^{18}$

An official who did not want his name to be revealed stated during an interview ${ }^{19}$ that the UNHCR, other international organizations, and NGOs failed to understand the critical position of the Turkish government. Because of its logistical importance, Turkey had to be very careful, especially about humanitarian aid sent to the region. He stated that Turkish authorities found military equipment in boxes of humanitarian aid, highlighting the skepticism of Turkish authorities who feared that some international organizations and NGOS were supporting terrorism in the area. He was emphatic that terrorism, trafficking in drugs and people, and the possibility that an Islamic regime might be transferred to Turkey from Iran were threats to the integrity of the country, and any support for these conditions was unacceptable to Turkey.

With the Gulf War, the unHCR's activities in Turkey expanded considerably; it opened sub-branches in Istanbul, Silopi, and Van. With a total of 8 international, 9 junior professional, and 27 national staff, it became the largest country program in the UNHCR.

In 1999, when 18,000 Kosovar refugees found asylum in Turkey under the joint UNHCR/IOM Humanitarian Evacua- 
tion Program, the UnHCR Ankara office and the Turkish government were more experienced with mass numbers of refugees. The Turkish government covered all the care and needs of the Kosovar refugees during their stay, and the UNHCR assisted in family reunification and monitored voluntary repatriation to Kosovo.

\section{The 1994 Regulation}

Exhausted from mass influxes, Turkish authorities introduced their own status determination in July 1994. Their regulation - entitled The Regulation on the Procedures and the Principles Related to Mass Influx and the Foreigners Arriving in Turkey either as Individuals or in Groups Wishing to Seek Asylum either from Turkey or Requesting Residence Permits with the Intention of Seeking Asylum from a Third Country-identified the Ministry of the Interior as the final decision-making body for status determination, in collaboration with the UNHCR. The regulation also stated that once a decision was made, the foreigners were entitled to live in a specific provincial city where they were responsible for signature duty.

Article 4 of the regulation stated that individual foreigners entering the country legally were required to apply within five days to the local governorate, and if they entered illegally, they were required to register with the governorate within five days, in the city where they entered the country. Article 6, which set out the decision-making procedure for the Interior Ministry, made no reference to appeals or to the review of negative decisions. Article 8 stated, "Without prejudice to Turkey's obligations under international law and considering the geographical characteristic of a mass influx, it is essential to stop such a movement and the advance of asylum seekers at the borders. The authorities in charge shall take necessary and effective measures to do so." ${ }^{20}$ Article 24 identified the responsible bodies in the event of a mass influx:

In order to administer any possible mass influx near our borders and to organize the co-operation, a Minister of State or the Ministry of Interior as appointed by the Prime Minister shall be in-charge. Representatives of the Turkish General Staff, the Ministry of National Defense, the Ministry of Interior, the Ministry of Foreign Affairs, the Ministry of Finance, the Ministry of Health, the Ministry of Communications, the Ministry of Agriculture and Village Affairs, other ministries and organizations concerned along with the National Intelligence Services and Turkish Red Crescent Society shall form a provisionary main coordination committee. The secretarial duties of this committee shall be performed by the ministry in charge.
Article 29 also permitted the deportation of refugees and asylum-seekers legally residing in Turkey, for reasons of national security and public order.

Although the UNHCR considered the regulation a major development in Turkey's refugee policy, it did raise some concerns. As a result of the five-day limit in the asylum application, there were a number of refoulement cases. Deportation of refugees and asylum-seekers legally residing in Turkey for reasons of national security and public order caused alarm for the UNHCR because martial law was already in force in the southeastern part of the country. ${ }^{21}$ Furthermore, the UNHCR had no official role in the internal appeal procedure, and was informed about the list of rejected claimants.

Interference with their sovereign right to deport people, as Kirisci notes, ${ }^{22}$ created considerable resentment among the Turkish authorities, and led them to accuse the outside world of interfering in Turkey's domestic affairs. The 1994 regulation was a means to protect the state as an absolute decision-maker on its borders and refugee policies. For that reason, it was a challenge for UNHCR to convince Turkish authorities to soften their implementation of the regulation and to be more cooperative.

\section{Conclusion}

In the last decade, the UNHCR has played a constructive role in the creation of Turkish refugee policy. By increasing its sub-branches around the country, it has not only played an important part in ensuring access to fair and efficient status determination for non-European refugees, but also promoted public awareness about the issues pertaining to them. On several occasions, UNHCR advocated reform when international standards were not being met. For example, Turkey's implementation of the 1994 regulations led to an increase in the number of refoulements. UNHCR responded by preparing a report that explained the flaws in the regulation and their consequences for Turkey's compliance with international obligations. In June 1995, UNHCR formally presented this assessment to the government. Since then, UNHCR Ankara has regularly engaged in dialogue with Turkish authorities in order to improve procedures. As a result, at least in part, no refoulement of recognized refugees was recorded after this date.

An important amendment to the 1994 asylum regulation extended from five to ten days the deadline for application following entry into the country. This greatly reduced the number of extra-procedural refugees.

Closer cooperation with the government in training activities also increased government confidence in the fairness 
and impartiality of UNHCR's advice. Furthermore, during two major earthquakes that caused enormous casualties and material loss, the UNHCR provided emergency relief to earthquake victims and gained the respect of the Turkish public. In the context of Turkey's candidacy for membership in the European Union, UNHCR helps Turkey to uphold the best international practice for the protection of refugees. As a candidate Turkey is also expected to have produced a National Plan of Action for Adoption of the EU Acquis (NPAAA) asylum standards. UNHCR will seek close coordination and compatibility between its own program and the NPAAA.

By covering the administrative costs of its implementing partners in Turkey, the UNHCR created a well-built civil society that keeps promoting the rights of refugees and asylum seekers. It also provides an intellectual forum for refugee issues. By organizing seminars, exhibitions of photographs, and television programs to improve public awareness aimed at the Ministry of Justice, police, judges, universities, NGOs, bar associations, and civil society, the UNHCR managed to form a more receptive and well-informed public opinion. In the UNHCR 2001 Global Appeal, UNHCR Ankara stated that its main goal was to persuade and assist the government to create a specialized Office for refugee status determination. The creation of this specialized Office would also be necessary in the context of an eventual transfer of responsibility for refugee status determination for non-Europeans from UNHCR to the state.

A review of the last ten years of the refugee situation and the improvements in refugee law in Turkey reveals that the UNHCR's constructive and flexible approach serves as a success story. The UNHCR Turkey Office realized the realities and the challenges in its program, and, instead of trying to implement a rigid line to refugee issues, adopted a more flexible approach that included cultural and social aspects. UNHCR analyzed Turkish culture and politics well, and managed to transform some challenges into its strengths.

\section{Notes}

1. Hannah Arendt, The Origins of Totalitarianism (New York: Harcourt Brace, 1951), 287.

2. Überfremdung is a term used by German-Austrian anti-immigrant parties.

3. Sadako Ogata, "Refugees: A Comprehensive European Strategy" (speech to the German un Association and the German Association for Foreign Policy, New York, 1994).

4. Arthur Helton, "Displacement and Human Rights: Current Dilemmas in Refugee Protection," Journal of International Affairs 47 (1994).

5. Karen Jacobsen, "Factors Influencing the Policy Responses of
Host Governments to Mass Refugee Influxes," International Migration Review 30 (1996): 655.

6. When a state responds to an issue as a threat to internal or external security, it treats that matter as one of high politics, and its approach becomes increasingly aggressive and militaristic. Low politics, on the other hand, require a more peaceful, humanitarian approach. In this case, the refugee issue is a security concern for Turkey. But not so for the United States.

7. Jacobsen, "Factors Influencing Policy Responses."

8. Charles Keely, "How Nation-States Create and Respond to Refugee Flows," International Migration Review 30 (1996): 1046.

9. Jacobsen, "Factors Influencing the Policy Responses of Host Governments," 678.

10. UNHCR, UNHCR Background Paper on Refugees and Asylum Seekers, 1997, 15.

11. Kemal Kirisci, "Refugees and Turkey since 1945" (research paper, Bogazici University, 1994), 22.

12. Bill Frelick, "Turkey: Displacement and Denial" (research paper, U.S. Committee for Refugees, 1999), 4.

13. UNHCR, UNHCR Background Paper, 23.

14. Elif Ozmenek, "Field Notes" (Ankara: UnHCr Ankara Office, 1997), 22.

15. Signature duty is the close monitoring of refugees' daily activities.

16. Ayin Tarihi Journal, August 31, 1988, 111.

17. Kemal Kirisci, "Refugee Movements and Turkey," International Migration 29 (1991): 545.

18. Kemal Kirisci, "Is Turkey Lifting the Geographical Limitation? The November 1994 Regulation on Asylum in Turkey," International Journal of Refugee Law 8 (1996): 45.

19. Elif Ozmenek, "Field Notes" (Ankara: Minister of the Interior, 1997).

20. Ibid., 47 .

21. Ahmet Icduygu, Fuat Keyman, "Globalization, Security and Migration: The Case of Turkey." (Paper prepared for the Session on Security and Migration at the Conference on International Migration: Challenges for European Populations, Bari, Italy, 1998), 20.

22. Kemal Kirisci, "Is Turkey Lifting the Geographical Limitation? The November 1994 Regulation on Asylum in Turkey," International Journal of Refugee Law 8 (1996): 45.

Elif Ozmenek received her master's degree from Columbia University, School of International and Public Affairs. Ms. Ozmenek works as a program development specialist for the Institute for International Research's Public Policy division. 